\title{
Law Enforcement Criminal Fighting of the Fish Stealing
}

\author{
Dr. H. Joni, SH.MH., \\ Notary, Lecturer at Habaring Hurung Law School Sampit, Central Kalimantan
}

\begin{abstract}
Law No. 45 of 2009 concerning Amendments to Law Number 31 of 2004 concerning Fisheries, does not regulate the distribution of authority explicitly nor does it regulate definitive work mechanisms, so that the three agencies, namely the Ministry of Fisheries and Maritime Affairs, the Department of Islamic State and Regional Governments state their institutions are both authorized to enforce fisheries law and without any system integration in their implementation. Conflicts of authority like this are not beneficial and reflect law enforcement against fisheries criminal offenses considered weak and not optimal, so that the impact on illegal fishing activities still shows a high enough frequency and continues to continue. For this reason, a solution is immediately sought, in order to create an orderly, safe condition and legal certainty. This has a positive effect on businesses in the field of fisheries, which in turn can improve the welfare of the community. In accordance with the above, it is necessary to improve the ability and competence of human resources, especially at the prosecution and court level so that in the process of resolution or law enforcement against Illegal Fishing can be done professionally and on target so that it is expected that the objectives of the integrated criminal justice system in tackling crime in the field of fisheries can be achieved. Likewise, it is necessary to establish a Coordination Forum for Law Enforcement Officials in the field of Fisheries so that in the handling of criminal fishing cases Illegal fishing can be carried out jointly across sectors so that what becomes an inhibiting factor in law enforcement efforts in the field of fisheries can be minimized.
\end{abstract}

Keywords: Law Enforcement, Fish Theft, Criminal Law

DOI: $10.7176 / \mathrm{JLPG} / 96-07$

Publication date: April $30^{\text {th }} 2020$

\section{Background of the Problem}

One of the reforms in the field of law and legislation carried out by the Republic of Indonesia is the enactment of Law Number 31 of 2004 which was later amended by Law Number 45 of 2009 concerning Fisheries. For the Republic of Indonesia, this law is very important considering the vast territory of the Republic of Indonesia, which is close to 6 million square kilometers covering national sovereignty and jurisdiction, requires our attention and concern, all of which concern law enforcement efforts and safeguarding the sea from disturbances and foreign party efforts.

The existence of Law No. 45 of 2009 is a positive step and is a foundation / rule for Law Enforcement and Fisheries Judges in deciding legal issues related to Illegal Fishing, whose impact is very detrimental to the state and has even been allegedly able to damage the nation's economy. Furthermore, illegal fishing activities in Indonesian waters cause state losses to average between 4 and 5 billion (USD / year). Every year around 3,180 foreign fishing vessels operate illegally in Indonesian waters.

Law enforcement against illegal fishing using the rule of law Law No. 31 of 2004 which has been changed to become RI Law No. 34 of 2009 concerning Fisheries, is expected to be able to eradicate illegal fishing mafia in order to save the country's wealth in the fisheries sector. The eradication of illegal fishing using these instruments has set the penalties against the perpetrators. Basically, punishment can be interpreted as imprisonment by a judge who is a conclusion or realization of a criminal provision in the law which is something abstract. Criminal punishment is a matter relating to a criminal / punishment such as the purpose or intention of imposing a criminal. Furthermore according to Muladi, the elements contained in a crime include:

1. The criminal is in essence an imposition or suffering or sorrow or other unpleasant consequences,

2. The criminal is intentionally given by a person or entity that has power (by an authorized person)

3. The crime is imposed on someone who has committed a crime according to the law.

Illegal fishing known as illegal, unregulated, unreported fishing does not only occur in Indonesia alone, several countries in the Asia Pacific region recognize that illegal fishing is an enemy that must be eradicated for sustainable fishing efforts. Data - ships captured by warships, their mistakes vary greatly including unauthorized transfers, fake documents, fishing with forbidden nets, using explosives, ABK does not have permission / documents and violations of facilities, especially immigration and foreign workers who are not have a work permit.

In addition, several fundamental problems in illegal fishing include uncertainty and unclear law, chaotic licensing bureaucracy. Legal uncertainty is characterized by several things such as different understandings of existing rules, inconsistencies in application, discrimination in law enforcement for violating foreign vessels, disputes between local businessmen, foreign businessmen and the judiciary. Judgment against customers is slow, protracted and corrupt. 
In Law Number 9 Year 1985 as well as Law Number 45 Year 2009 concerning Amendment to Law Number 31 Year 2004 Concerning Fisheries, it is very clear that illegal fishing is sentenced to imprisonment and a fine commensurate with the violations committed. Imprisonment sanctions and fines are not applied properly. Other ambiguities are the penalties / sanctions against the licensing bureaucracy and the supervisors and law enforcement officers at sea who deliberately charge outside the provisions or pass offenders with collusion.

Therefore law enforcers such as KKP employees, Water Police and Navy are expected to be able to optimally protect our seas from fish theft and other crimes. The establishment of the Ad hoc Fisheries Court is also expected to be able to answer the problem of fish theft crimes that are reflected in the decisions made, both crimes committed by Indonesian citizens or those committed by foreign citizens / countries and from these decisions are expected to have a deterrent effect for the perpetrators of the Illegal Fishing crime.

Of the many fields of law, it can be said that criminal law is ranked first which not only gets the spotlight but is also an incredible reproach compared to other fields of law. The criminal law field is the easiest legal field to be used as an indicator of whether the legal reforms that have been carried out in the Indonesian State have been going well or not.

Criminal law does not only talk about the Court's decision on handling criminal cases, but also covers all criminal justice processes and systems. The judicial process begins with an investigation by the Police and culminates in criminal conviction and then ends with the execution of the sentence itself by the Penitentiary. All of these criminal proceedings are currently getting a lot of attention from the community because of their performance or the behavior of their officials that are far from what is expected.

The problem of fisheries, and then also develops to the problem of maritime affairs, is administratively declared by the authority of the Ministry of Maritime Affairs and Fisheries (KKP), so complex. Like the flow of water, simple about fish, for example. Ocean Advertising. Starting from the upstream, the capture, the technology, the natural factors, the regulatory authority, the fishing area or the sea, and the point is very broad. The complex and the sub-problems give birth to the following sub-problems, to the more technical ones.

Not to mention views from a social perspective, technical perspective and / or a deeper perspective. From a simple description, or from a technical point of view in relation to the management of the fisheries sector in relation to abroad, as another example. Based on data from the Ministry of Maritime Affairs and Fisheries (KKP), from January to mid-September 2017, 107 illegal fishing vessels have been captured, consisting of 68 Vietnameseflagged KIA (Foreign Fish Vessels), 4 Philippine-flagged MCHs, and 9 Malaysian flags. While 26 other Indonesian-flagged vessels. The arrest certainly did not stop at that action. Next is how the solution going forward.

In addition, the Ministry of Maritime Affairs and Fisheries also stated that the challenges faced by the national fisheries processing industry in the future will be heavier but are optimistic that the various challenges will be answered. Optimistic may, but of course thirst is accompanied by a variety of efforts that match the weight of the challenge. So vast is the Indonesian sea that requires technology that is not only sophisticated but also in very large quantities.

Whereas the issue of law enforcement against fisheries crime especially those that are cross-country in nature has often occurred comprehensively and extensively. Starting from the planning of fishing also related to insurance, ownership and licensing of ships, to corruption in obtaining permits. Including document forgery, tax evasion, money laundering, mixing with trafficking in persons and illegal drugs and so on. The point is related to broad and complex problems.

The crime also involves many parties domiciled in various countries. One example of the famous fish theft is the Viking Viking Ship. This arrest is an illegal fishing practice and violates a country's sovereignty. This ship has 25 flags so the ship can change flags at any time. They also easily forged registration and licensing documents. For this reason, various parties must find solutions to the limitations that are sometimes possessed by laws and regulations.

Because it is a transnational crime or international in nature, fish theft or illegal fishing is a common problem especially for countries that have sea territories. As a kind of finding common understanding, an International Symposium on Fisheries Crimes was held. This important symposium is a continuation of the previous symposium which was held in Yogyakarta (October 2016) and Cape Town, South Africa (Ceptember 2015). .

In the international community, the fishing industry must be prepared to face more severe challenges going forward. Globally, the fishing industry, especially canning, tends to face decline. This conceptually relates to Fish Resources which cannot always be constant because it depends on the season. That is why, the industrialization of fisheries, especially canning requires special arrangements.

Presidential Regulation No. 3 of 2017 concerning the Action Plan for the Acceleration of the Development of the National Fisheries Industry as its legal basis is not hampered by various obstacles, especially bureaucracy and coordination that are not actually needed or can be eliminated. Thus, the hope is that this Perpres can be implemented optimally in accordance with the potential and personal dedicated to fisheries and marine issues. 


\section{Orientation of Fisheries Resource Management}

Natural Resources has a very significant economic value and meaning, even a potential of natural resources in each region is often the backbone in the process of realizing the existence and continuity of life in the community, nation and state. Considering the existence and potential of natural resources in Indonesia are considered quite large, the national economic development which is the main activity in national development tends to make Natural Resources as the main capital of development, but ironically the policies and processes have not included aspects of efforts to prevent exploitation and or exploration which is destructive and or provides depreciation or depletion for the existence of these natural resources (especially the Natural Resources in the fisheries sector).

The geographical condition of Indonesia as an archipelagic country, which is two-thirds of its territory is sea waters consisting of coastal sea, open sea, bay and strait, has a beach length of 95,181 km, with a waters area of 5.8 million $\mathrm{km}^{2}$, rich in marine and fish resources. The 5.8 million $\mathrm{km}^{2}$ water area consists of: (1) territorial sea waters 0.3 million $\mathrm{km}^{2}$, (2) archipelago waters 2.8 million $\mathrm{km}^{2}$, and (3) the waters of the Indonesian Exclusive Economic Zone (EEZ) 2, 7 million $\mathrm{km}^{2}$.

With the enactment of the 1982 United Nations Law of the Sea of the Sea (United Nations Convention on 1982 - UNCLOS 1982) ratified by Law of the Republic of Indonesia Number 17 of 1985, Indonesia's sea area expanded to approximately 8.5 million kilometers square. In addition, UNCLOS has opened a new chapter on the determination of territorial boundaries and jurisdictional authority at sea, where in this connection the Republic of Indonesia as an "Archipelagic State" legally has territorial borders and jurisdictional authority over inland waters (Internal Waters), archipelagic waters, territorial seas (Territorial Sea), Exclusive Economic Zone, high seas (sea) as well as continental shelf and clearer international seabed.

The potential of marine fisheries if cultivated optimally while still adhering to environmentally friendly fishing will have an impact on the following:

1. Increased foreign exchange from exports of marine fisheries commodities,

2. Improvement of nutrition, especially animal protein for the people,

3. Increased income / income to improve the welfare of fishermen.

The potential described above is only about $40 \%$ of the sustainable potential cultivated. $90 \%$ of the total fishery production comes from small-scale fisheries or small-scale fisheries, which in fishing efforts are carried out using various types of fishing equipment which are generally still traditional in nature.

The main problem faced in the management of fisheries resources is that economic policies have tended to be more biased towards exploitation of fisheries resources, resulting in weak institutional management and law enforcement. In addition, the application of the principles of sustainable development into government systems, organizations and work programs, both at the central and regional levels, is still not going well. Therefore, one of the amendments to Law No. 9 of 1985 concerning Fisheries is the issue of law enforcement, which is considered a very important and strategic matter in order to support fisheries development in a controlled manner and in accordance with the principles of fisheries management.

According to Dahuri that some of the main factors threatening the preservation of marine biodiversity resources are:

1. Over exploitation of biological resources;

2. The use of fishing techniques and equipment that damage the environment;

3. Changes and physical degradation of habitats;

4. Pollution;

5. Introduction of foreign species;

6. Conversion of protected areas to other development purposes; and

7. Global climate change and natural disasters.

Utilization of Indonesia's marine resources to date has been considered by many as not optimal. Although actually the management or utilization of Indonesian marine resources has long been carried out by a number of departments and non-departmental government agencies / agencies. One of the weaknesses of the main tasks and functions carried by most of these institutions is actually not in the field of maritime affairs or in the sea area, such as mining, transportation, agriculture, forestry, land, defense, and tourism.

However, in practice, these departments and institutions have general authority to carry out plans, programs and policies that are not limited to national areas, including sea areas. However, because for so long their task and authority orientation has more to do with the terrestrial area, their approach tends to be more land-oriented in general.

Though the conditions of the terrestrial and sea / waters are very different. One example is that the ocean cannot be clearly marked with borders, so it is not uncommon for conflicts of interest, overlapping, and the implementation of policies is often not harmonious between one institution and another. The number of departments, agencies and government agencies with an interest in the utilization of marine resources did not necessarily make this sector develop into a national economic mainstay sector. On the contrary, because there are too many interests, the direction of the development policy of the marine sector is unclear. Therefore, at this time 
it is very much needed firmness and commitment of the government to further drive the acceleration of marine and fisheries development, because without this it is impossible that the sector can make a major contribution to the national economy.

Based on the things stated above, for now it is necessary to study the existing regulations, namely the extent to which the substance of each of these regulations is compatible with one another and formulate a system, namely the system of regulation (regulation) management of sources integrated marine power. The basic consideration is that without harmonization and synchronization of regulations which form the basis of marine resource management activities issued by sectoral institutions, the management conditions will continue as they are at the moment, and it is not even impossible to further worsen the condition of Indonesia's marine resources. in the future.

\section{The Development of Fisheries Sector Management from Time to Time a. Dutch Colonial Period}

The Dutch East Indies Colonial Period (Nederlandsch Indie) is a period of institutionalizing institutions dealing with community affairs to establish Dutch colonial power over the territory of the Dutch East Indies, including the affairs of coastal communities which rely on economic activities on marine resources. During this period the management of the maritime sector was still very simple and limited to the use of fisheries and media relations or transportation.

The regulation of the marine sector during the Dutch East Indies was carried out since the beginning of 1900 with the development of the fisheries sector. In 1905 fisheries affairs were transferred from the Department of the Interior to the Department of Agriculture (Department of van Landbouw, Nijverbeid en Handel which was later changed to Department of Van Ekonomische Zaken). In the same year, Het Visscherij Station was established under the Department of Agriculture in Jakarta. The fisheries activities of that period were classified as agricultural activities, although in 1915 a kind of Fisheries Service was established as a special organization that handled marine fisheries under the Van Ekonomische Zaken Department, namely the Zee Visserij Parts which was part of the Afdefing Cooperatie en Binnenlandsche Handel.

As for the research and development activities of marine fisheries, a colonial government research institute called the Institut voor de Zee visserij was formed. In 1931 there was a reorganization in the structure of the Dutch East Indies government, among others by expanding the scope of the authority of the Department of Agriculture to become the Department of Agriculture and Fisheries. In connection with maritime affairs, in 1911 the Burgerlijk Openbare Werken was formed which changed its name to the Department of Verkeer en Waterstaat in 1931.

During the Japanese occupation of 1942-1945, arguably there were no significant changes in the regulation of Indonesian marine resources. Van Ekonomische Zaken's department changed its name to Gunseikanbu Sangyogu. The functions and duties of this department have not changed from the functions and duties of the colonial era. The same is true for research and development institutions, although it changed its name to Kaiyoo Gyogyo Kenkyuzo and based in Jakarta, it did not experience changes in function.

In fact, the Law on sea boundaries has not changed. But what should be noted is precisely during the Japanese occupation there was an expansion of government fisheries institutions. During this time, fisheries lighting services were formed in the regions called Suisan Shidozo. In addition, during this period there was a union of inland fisheries with sea fisheries, although they were still included in agricultural activities.

\section{b. Period After Independence.}

When the Republic of Indonesia was proclaimed on August 17, 1945, the territory of the Republic of Indonesia at that time was the entire territory of the Dutch East Indies. The regulation of Indonesia's marine territories is also still based on Territoriale Zee en Maritieme Kringen Ordonnantie S.1939-442. According to the Ordinance, Indonesia's territorial sea boundary is 3 nautical miles measured from the coast. Thus, the waters located between the Indonesian islands at that time were international territory (free sea). Indonesia's sea area with the sea legal regime as mentioned above is only about $100,000 \mathrm{~km}^{2}$. Physically, the Indonesian islands are separated by the sea, even though culturally, the territorial concept does not distinguish mastery between the sea and land, given the concept adopted by the Indonesian people who named the country's territory as the homeland.

On that basis, in the first decade of the period of independence efforts mainly focused on territorial consolidation and tended to focus on the political-security aspects of the region, given the number of rebellions that led to efforts to disintegrate the nation. On December 13, 1957 the Government of the Republic of Indonesia through the Prime Minister Ir. Djuanda issued a declaration which claimed all waters around, between and connecting the islands of Indonesia as a national territory.

The above declaration which came to be known as the Djuanda Declaration, which states: "That all surrounding waters, including and which connect islands or parts of islands that are part of the land of the Republic of Indonesia, irrespective of the extent or width are parts that are reasonable than the mainland area of the Republic of Indonesia and as such is part of national waters under absolute sovereignty of the Republic of Indonesia.

Peaceful sea traffic in these inland waters for foreign vessels is guaranteed as long as and is not in conflict with the sovereignty and safety of the State of Indonesia. The determination of the territorial sea boundary which 
is 12 miles wide measured from the lines connecting the outermost points on the islands of the Republic of Indonesia will be determined by Law.

The Juanda Declaration is a correction to territorial arrangements, especially at sea, during the Dutch East Indies era and at the same time political actions intended to guarantee the creation of a territorial integrity of Indonesia.

In addition to efforts aimed at the political-security aspects of the region, efforts to reform the development of the marine sector continue to run at the level of government. After the Proclamation of Independence on August 17, 1945, the government of the Republic of Indonesia established the Department of People's Prosperity. Under this department there is a Fisheries Service that deals with land and sea fishing activities. Since the first cabinet was formed on September 2, 1945 until the formation of a third parliamentary cabinet on July 3, 1947, the Office of Fisheries remained under the Agricultural Coordinator, in addition to the Trade Coordinator and Industry Coordinator in the Ministry of People's Prosperity.

Although the People's Prosperity Department later underwent a change in its organizational structure due to the Dutch military aggression I and 11 as well as the transfer of the country's capital to Yogyakarta, the Fisheries Service remained a subordinate of agriculture. On January 1, 1948, the Ministry of Prosperity underwent a restructuring by removing coordinators. Instead, five high ranking employees were appointed under the minister, namely High Employees in Trade, Agriculture and Animal Affairs, Plantation and Forestry Affairs, and Education Affairs. the Fisheries service is part of Agricultural and Animal Affairs.

During the recognition period of Indonesian sovereignty on 27 December 1949, the Ministry of Prosperity was later divided into two Departments: (1) the Department of Agriculture; and (2) Ministry of Trade and Industry. The Office of Fisheries enters the Department of Agriculture. The Department of Agriculture on March 17, 1951 underwent a change in its structure, namely the appointment of 3 Coordinators dealing with issues of Agriculture, Plantation and Animal. Under the Agricultural Coordinator, the People's Agriculture agency was formed.

The Fisheries Bureau at that time had developed into the Marine Fisheries Bureau, the Land Fisheries Office, the Fisheries Investigation Office, and the Marine Fisheries Foundation. All these departments are under the People's Agricultural Service. This structure does not last long. On April 9, 1957, the composition of the Department of Agriculture underwent another change with the formation of the Directorate of Fisheries and under that directorate the fisheries services were coordinated.

On July 5, 1957, President Soekarno issued a Decree to return to the 1945 Constitution. Correspondingly, the nomenclature in the Ministries changed and the term directorate returned to service. However, in 1962, the Ministry of Agriculture and the Ministry of Agriculture merged and the term directorate was reused. During the post-decree presidential cabinet, the Directorate of Fisheries has developed into several departments, namely the Department of Land Fisheries, Marine Fisheries, Marine Fisheries Research Institute, Land Fisheries Research Institute, Fisheries Business Education Institute and Fisheries BPU.

Political and security conditions that were considered unstable caused the government to overhaul the cabinet structure and the Dwikora Cabinet was formed in 1964. In this Dwikora Cabinet, the Ministry of Agriculture was deconstructed into 5 departments and in this cabinet the Department of Land / Sea Fisheries was formed under the Agriculture and Agrarian Compartment under the Agriculture and Agrarian Compartment . The establishment of the Department of Land / Sea Fisheries is the government's response to the results of the First Fishermen Conference which resulted in the recommendation of the need for a special department that handles the thinking and management of efforts to improve fisheries development. Through the formation of the Refined Dwikora Cabinet, the Department of Land / Sea Fisheries is no longer under the Agriculture and Agrarian Compartment but is under repositioning and under the Maritime Compartment. Under the new compartment, the department has changed its name to the Department of Fisheries and Marine Wealth Management.

\section{c. Period of Restructuring and Reorganization of Marine Institutions in the New Order and Reform Government (1966-1999).}

At the beginning of the development journey of the New Order, the Indonesian people inherited quite severe economic conditions. Inflation in 1966 reached around 650 percent. The social, political and economic structure of the Indonesian people at that time, as a result of the legacy of Guided Democracy and Guided Economy during the Soekamo (Old Order) era, almost collapsed.

The choice of the New Order Government to overcome the severe economic conditions in 1966 and 1967 was to try to improve physical infrastructure, institutional restructuring, restore production activities and curb inflation. During the period 1967-1969, President Soeharto's administration tried to lay a solid foundation for the implementation of long-term development. The stages of development in 1967-1969 were the first period or stages of Indonesia's economic stability and rehabilitation. Since April 1969, the New Order Government began to formulate a national development strategy by laying out or emphasizing development in an effort to achieve high growth. This high economic growth strategy is then translated into the Development Trilogy, namely high economic growth, national security stability and equitable distribution of development results.

To support that, the government then carried out the restructuring and efficiency of government organizations, 
including the Department of Land / Sea Fisheries. In the restructuring process, the Ampera Cabinet which replaced the Dwikora Cabinet established a cabinet composed of a presidium and 24 departments. Fisheries and maritime affairs are handled by a department called the Maritime Department, which consists of three directorate generals (directorate general) namely the Directorate General of Sea Transportation, the Directorate General of Maritime Industry, and the Directorate General of Marine Wealth Management. After the Ampera Cabinet disbanded, the Directorate General of Marine Wealth Management was then repositioned again and merged into the Directorate General of Fisheries under the auspices of the Ministry of Agriculture, since the formation of the Development Cabinet.

Throughout the New Order government, activities in the field of fisheries were only handled by institutions at the directorate general level. Through Presidential Decree 163 of 1966, the Department of Oil and Gas and the Department of Mining were merged into the Department of Mining, subsequently changed to the Department of Energy and Mineral Resources. The next sea transportation is under the Department of Transportation.

The fisheries sector, especially those which have directorate general level institutions have never been able to drive the process of social and economic transformation in coastal communities. Considering the broad responsibility, which concerns the wealth of national water resources that almost covers $3 / 4$ of the national territory, the role played by the Directorate General of Fisheries has never been optimal. This is because the directorate general's institution does not have a strong bargaining position when it faces the interests of other institutions that are higher in the priority hierarchy, so that the level of political negotiation is always defeated. For example, facing the industrial sector, tourism, mining, defense, and others.

Entering the era of reform when President Abdurrahman Wahid was elected and through the struggle of various sea-based institutions, such as the Center for Coastal and Ocean Resource Studies, Bogor Agricultural Institute (PKSPL-IPB), Nusantara Fisheries Community (MPN) and various NGOs, to convince various factions in People's Consultative Assembly of the Republic of Indonesia, a development paradigm shift gradually began to occur, so that the Department of Sea Exploration was formed. This department was later changed to the Department of Marine Exploration and Fisheries, and finally the Department of Maritime Affairs and Fisheries.

Presumably, the government can learn the lessons of the failure of the transformation of development in the Old and New Order eras, so that the current development orientation is focused on optimizing the use of natural resources owned by the Indonesian people. One of those strengths is marine resources. However, this institutional struggle needs to be followed up with the development of comprehensive marine policies, so that these marine resources can make a real contribution to the development of the welfare of the Indonesian people.

\section{d. Ocean Policy and Ocean Economics Vision in the Regional Autonomy Era (1999-present).}

Ocean Policy as a strategic policy is expected to bring the prosperity of the people, develop the dignity and dignity of the Indonesian people, and be able to equalize with the developed countries in the world. The policy is based on scientific objectivity (scientific objectivity) which is built on the basis of participatory principles and is directed so that people become the biggest beneficiaries. Ocean Police is further supported by economic development instruments with a vision of OCEAN ECONOMICS that is able to use marine resources wisely for the welfare of the Indonesian people in a sustainable manner.

With regard to the paradigm and vision of marine development in the future, that the doctrine of sustainable development (sustainable development) agreed at WSSD in Johanesburg, September 2002 includes the marine area. This doctrine has become a new ideology of the development of third world countries, such as Latin America, Asia, and Africa whose implementation is often questioned, because developed countries such as the United States are also 'hindering' the Kyoto Protocol. This means that the doctrine is only a document. If this happens, the effectiveness of the concept to achieve the target is very low. Therefore, there is a perception that in essence this concept is unconsciously an instrument of "hegemony" of developed countries towards developing countries as an instrument of international trade to pressure developing countries, if developed countries that have ratified it remain, do not carry out world commitments on the importance of the environment for humanity.

Failure of the doctrine of sustainable development can destroy renewable resources in third world countries, such as forests and fisheries resources, because the costs incurred are borne by developing countries themselves, while developed countries continue to increase economic expansion activities by damaging the environment. And what is most severe is if the application of the concept of sustainable development does not create social justice and prosperity but rather what happens is structural poverty which is increasingly unstable in developing countries, while developed countries do not care.

In addition, developed countries do not provide good examples so it is not a wrong concept but its implementation gives a negative signal. In fact, in the concept of sustainable development the results of the formulation of the World Commission on Environmental and Development (WCED) are developments that meet the needs of the present without reducing the ability of future generations to meet their own needs. In this concept there are essentially two main substances, namely:

1) the concept of needs, specifically basic needs for the welfare of the poor and future generations, and;

2) ideas about limitations originating from the state of technology and social organization. imposed on the ability 
of the environment to meet present and future needs.

Indonesia must have a clear maritime policy and attitude and be outlined in the blueprint of the National and Regional Development Program, so that sustainable development in the marine sector is adjusted to national and regional needs. Meanwhile in the international forum, a lobby was carried out so that the developed countries would also seriously implement the country. developing also benefits.

Thus it is hoped that there will be no "coercion" of sustainable development paradigms by developed countries to developing countries and "castration" of development traditions that have taken root in developing countries, such as local knowledge / wisdom that is proven capable of creating social justice and protection of natural resources. It is this increasing role of local communities in sustainable marine development that must be continuously developed.

This phenomenon has actually been predicted by Amartya Sen, who later won the Nobel Prize in Economics in 1998. Sen criticized the superiority of developed countries against developing countries that always impose the terminology of economic development they hold. With this foundation, Sen finally issued a new thesis that economic development is not merely pursuing the growth of production alone, but is an attempt to "liberate" society that leads to social justice, namely freeing themselves from structural poverty.

Ocean Policy is essentially expected to provide a large portion and attention for marine and fisheries development. This is because people who live in coastal areas have unique characteristics and dynamics, namely:

First, the sociological-historical angle and culture that influence it. Coastal communities show a pattern of attitudes and life cosmopolitanism / internationalism, dynamic, entrepreneurship, outward looking compared to rural communities. However, this ethos of socio-cultural marine ethos has been marginalized in the land hegemonistic development process.

Second, geographically, coastal and marine have different characteristics from land in terms of resources, so the level of risk in trying to be high (high risk), but also high acceptance (high return). Only relatively high technology and large capital are able to optimize the exploration and exploitation of natural resources and industrial development.

Third, there is a doctrine that applies universally. At sea, that the sea is open access (open access) or part of common property (common property), so that the level of competition in trying and competing for access to resources at sea is very tight and hard. Only actors who have skills, large capital, advanced technological levels and established business institutions are able to optimally mobilize their production levels and win the competition.

Fourth, not too different from other biological resources, coastal and marine resources are highly dependent on natural conditions such as the weather and the environment. Weather conditions will affect the periodization in business (for example at sea there are certain times for fishing and environmental conditions directly influence the availability and Environmental pollution will adversely affect the quality of the commodities produced. These unique characteristics and dynamics are now accompanied by social realities on the coast that poverty, underdevelopment, and regional or economic underdevelopment are phenomena inherent in the sector.

This reality can be seen from several things:

1. the inheritance of poverty in fishing communities which is a phenomenon of their daily lives;

2. the quality of human resources who have the ability and level of formal education is still low. The education level of fishing communities can be classified as low according to their level of education: $68.1 \%$ did not complete elementary school; $28.2 \%$ only graduated from elementary school; $3.7 \%$ have education levels above elementary school;

3. sectoral conflicts that equate the issue of utilization of coastal and marine resources;

4. low level of technological innovation, due to the flow of capital (investment) to the sector and for this region has not been able to encourage changes in the level of technology utilization of resources for para. fishermen and other coastal community groups.

Given the unique characteristics and dynamics of the coast and the inherent reality, mistakes in implementing development policies on the coast and the ocean will lead to the marginalization and underdevelopment of new styles for the majority of coastal communities in the present and future. The demand to immediately make a large contribution to GDP (Gross Domestic Product) through the opening of the maximum investment valve becomes a necessity, because it requires a process. With policy adoption. maritime affairs that are responded positively by investors, both from within and outside the country should be allocated according to sector priorities and readiness.

As such, it takes a lot of effort to attract investors to invest in the marine sector. For Indonesia, the phenomenon of investment globalization like this should be directed to the development of investment in the marine tourism and fisheries sector, because the level of efficiency is high, and can absorb employment. On the other hand, as a result of regional autonomy policies that give authority to local governments, so that local governments have the right to take and formulate policies in the management and utilization of marine resources.

However, in the regions there are still classic problems which are the main problems in the economic development of coastal communities. In the fisheries sector, the problem is the economic dependence of fishermen and fish farmers on economic actors with large capital. This form of dependency is: 
(1) financial-industrial dependence: fishing communities and fish farmers are the main elements in the production process, as actors or workers, while economic activity is dominantly controlled by industrial forces and financially controlled by large capital owners;

(2) industrial technology dependency: business units and industries in coastal areas may be owned by local fishermen (traditional, small, or medium), but the technology is controlled or owned by multinational companies with large capital.

This is what the Neo-Marxists (adherents of dependency theory) consider to be an asymmetrical relationship between the center, which is the owner of large capital and periphery / satellite. In this connection, there is a 'dependable' dependency relationship "especially in terms of capital / financial, managerial, technology, and input. In other forms, the development process is named or characterized by the expansion characteristics of individual or group owners. Ownership in the marine development process is in the form of access to marine economic resources is generally only controlled by large investors who have access to authority.

If such conditions are maintained in the process of economic development on the coast and the ocean, what happens is the strengthening of the hegemony of large capital owners and local bureaucracy. Capital accumulation that occurs will only be absorbed by the owners of capital and not by the public or not even invested in the economic sectors in the marine sector. Thus, the occurrence of economic growth in the marine economic sector depends only on large investors and local authorities so that investment cannot develop expansively on economic activity in the marine sector, but rather is more consumptive in culture or rushed to other sectors.

Such conditions create a lot of criticism which then creates new thinking, namely that the process of economic development is no longer aimed at increasing GDP growth as high as possible but rather the elimination or reduction of poverty levels, overcoming income inequality, and providing employment in the context of a growing economy. On the basis of this thought, the concept of "redistribution of prosperity" emerged, as a substitute for or adjustment to the definition of growth.

In this perspective, development policies in coastal and marine areas should be developed. Meanwhile, in the planning process it is necessary to integrate non-economic factors, such as the involvement of local communities, local community culture, local value systems, traditional property rights systems, and the influence of religious teachings / criteria that are directly related to the modernization and population processes that are to be overcome. This kind of development process is known as participatory development. This kind of model has been developed in Japan which is known as Japanese-style human capitalism.

This model emphasizes the importance of "harmonious balance" between Japanese entrepreneurs and society in achieving material abundance through industrialization, also known as soft-economic. In this harmony, community revitalization and improvement of the quality of social life sought, namely through the balance between humanity and nature.

\section{Illegal Fishing and the Role of State / Government Apparatuses and Law Enforcement Officials in Efforts to Act Illegal Fishing Criminals \\ 1. Definition of fish theft (Illegal Fishing) and the mode of the culprit}

The definition of "illegal fishing" in existing laws and regulations is not explicitly defined explicitly. However, the term illegal fishing can be seen from the literal meaning of English.

In The Contemporary English Indonesian Dictionary, "illegal" means illegal, prohibited or contrary to law. "Fish" means fish or fish meat and "fishing" means fishing as a livelihood or fishing ground. Based on this literal understanding it can be said that "illegal fishing" according to the language means fishing or fishing activities carried out illegally.

According to Divera Wicaksono, as quoted by Lambok Silalahi, illegal fishing is using a fake fishing license (SIPI), not equipped with SIPI, the contents of the permit document are not in accordance with the ship and the type of fishing gear, fishing with prohibited types and sizes.

Law enforcement is a business or activity of the state based on state sovereignty or based on the provisions of applicable law, both national law itself and international law can be respected by any person and or legal entities, even other countries to fulfill their interests but does not interfere with the interests of other parties.

Law enforcement in the judicial sense is defined as a judicial process consisting of the activities of investigation, investigation, prosecution and examination in a court hearing and the implementation of a judge's decision, this aims to ensure order and legal certainty. Based on the legal meaning, what is meant by law enforcement at sea is a process of activities in the settlement of a case that arises as a result of violations at sea over the provisions of applicable law both international and national legal provisions.

Criminal offense / criminal act is an act that violates criminal law, and is therefore contrary to the law committed intentionally by a person who can be accounted for.

Fishing is an activity to get fish in waters that are not being cultivated by any means or means, including activities that use ships to load, transport, store, cool, handle, process and / or preserve them.

Fishing Permit, hereinafter referred to as SIPI, is a written permit that must be owned by every fishing vessel 
to carry out fishing which is an inseparable part of SIUP, while the Fishery Business Permit, hereinafter referred to as SIUP, is a written permit that must be owned by a fishery company to conduct fisheries business using the production facilities listed in the permit.

The rise of illegal fisheries in Indonesian waters has an impact on national and global fish stocks. This has also caused a downturn in the national economy and increased social problems in the Indonesian fishing community. There are at least ten main problems of illegal fishing activities that have had a serious impact on Indonesia. First, illegal fishing in Indonesian waters will threaten the preservation of national and even global fish stocks. Unreported or misreported fisheries practices, or under-reported reports, and unregulated fisheries will cause problems in the accuracy of data about available fish stocks. If the fish stock data is inaccurate, it is almost certain that fisheries management will be inaccurate and will threaten the preservation of national and global fish stocks. This can be categorized as illegal fishing practices.

Second, illegal fisheries in Indonesian waters will reduce the contribution of capture fisheries in the EEZ region or the high seas to the national economy (GDP). Besides also encouraging the loss of the fisheries resource chain that should be enjoyed by Indonesia. The Indonesian government claims that the loss from illegal fishing practices reaches US $\$ 4$ billion per year. If it is assumed that the price of illegal fish ranges between US $\$ 1,000$ - 2,000 per ton, every year Indonesia loses around 2-4 million tons of fish. Another calculation stated that the total loss of the state due to illegal fisheries reached US \$ 1.924 billion per year. This figure consists of violations in the area of operations of US \$ 537.75 million, fake documents of US \$ 142.5 million without documents or illegal US \$1.2 million and the use of foreign crew members of US \$ 780 million.

Third, illegal fishing leads to a decrease in labor in the national fisheries sector, such as fish collection and processing. If this is not resolved as soon as possible it will reduce the chance of the younger generation of fishermen to take part in fishing efforts.

Fourth, illegal fisheries will reduce the role of national fish landing sites (national fishing ports) and the receipt of harbor guide money. Because illegal fishing vessels generally do not land their catches at national fishing ports. This will have a significant impact on the reduction in national income from the fisheries sector.

Fifth, illegal fishing will reduce revenues from services and taxes from legitimate operations. Illegal fishing will reduce fisheries resources, which in turn will reduce the income of companies that have a valid fishing license.

Sixth, both directly and indirectly, the multiplier effects of illegal fishing have links to national fishing. Because national fishing activities will automatically decrease in line with the loss of potential fish resources due to illegal fishing activities. If the potential for stolen fish can be caught by the national fishing fleet, then it can at least guarantee sufficient raw materials for the fishery product processing industry, for example tuna canning. In general, fish stolen from Indonesian waters are tuna and other large pelagic fish. If each tuna canning industry requires raw materials of at least 80-100 tons per day or around 28,000 - 36,000 tons per year, then the stolen fish can support at least 42 national tuna canning industries.

Seventh, illegal fisheries will have an impact on ecosystem damage, due to loss of value from the coastal area, for example shrimp that are close to coastal fishing areas and from mangrove areas that may be damaged by illegal fisheries. Furthermore, it will have an impact on reducing income for people fishing on the coast.

Eighth, illegal fishing will increase conflicts with traditional fishing fleets. The rise of illegal fishing disturbs the safety of Indonesian fishermen, especially traditional fishermen in catching fish in Indonesian waters. In addition to illegal fishing, foreign fishermen also often shoot traditional fishermen who are fishing in the same fishing ground (fishing ground). Besides illegal fishing will also lead to a reduction in fishermen household income and will further worsen the situation of poverty.

Ninth, illegal fisheries have a negative impact on fish stocks and fish availability, which is an important source of protein for Indonesia. Reducing the availability of fish in the local market will reduce the availability of protein and national food security. This will increase the risk of malnutrition in society, and have an impact on the government's plan to increase the value of fish consumption.

Tenth, illegal fisheries will have a negative impact on the issue of gender equality in fishing and processing and marketing the results of fishing. Facts in several areas show that fishermen's wives have an important role in fishing activities on the beach and processing of catches, including for marketing fisheries products.

\section{Law Enforcement of Illegal Fishing in Indonesia}

Law enforcement against criminal acts in Indonesia is carried out through criminal justice processes as affirmed in Law No. 8 of 1981 concerning Criminal Procedure Code (Criminal Law Book) in which every form of criminal act that occurs is handled through the stages of Pre Adjudication, Adjudication and Post Adjudication .

Pre Adjudication is at this stage law enforcement agencies or agencies directly involved, namely investigators (Police, Navy and Civil Servant Investigators) and Prosecutors (Prosecutors). Law enforcers take actions based on information and reports regarding the existence of an illegal fishing act, but not infrequently there are also direct actions by the Police and the Navy on the findings of their own intelligence, as is often done by the Sea Safety Patrol Title by the two agencies. However, the results of the Maritime Security Patrol Title which will be processed at the next stage, will not run or be carried out optimally without the full and comprehensive coordination of 
various law enforcement agencies or that we are often familiar with as the Integrated Criminal Justice System (ICJS). .

Various other efforts have also been made by the government in efforts to safeguard the sea, but it is still considered inadequate in responding to the existing sea security challenges. Until finally the government felt the need to make efforts - coordination of various parties in efforts to safeguard the Indonesian sea. Efforts made by the government are to revitalize the existing Maritime Security Coordinating Board to be rearranged through the Presidential Regulation instrument. Changes in governance and the development of the strategic environment at this time need to reorganize Bakorkamla to improve coordination between government institutions / agencies in the field of maritime security. In 2003, through Kep. Menkopolkam, Number Kep.05 / Menko / Polkam / 2/2003, formed a Working Group on Security Development and Law Enforcement at Sea.

Finally on December 29, 2005, Presidential Regulation Number 81 of 2005 concerning the Maritime Security Coordination Agency (Bakorkamla) was stipulated, which became the legal basis for the organization. To create conducive regional security conditions, Lantamal I conducts limited Kamla operations with KAL / Patkamla defense equipment that are held in the ranks, in the context of upholding sovereignty and law and protecting natural resources for national and regional interests.

The implementation of Belawan's Lantamal I main tasks certainly refers to the Navy's main tasks mandated in article 9 of the Republic of Indonesia Law No. 34 of 2004 concerning the Indonesian National Army, namely:

1. Carry out the duties of the TNI sea dimension in the field of defense;

2. Uphold the law and maintain security in the sea territories of national jurisdictions in accordance with the provisions of national law and international law which have been ratified;

3. Carry out Navy diplomacy in order to support foreign policy set by the government;

4. Carry out the tasks and the development of the strength of the sea dimension;

5. Carry out the empowerment of marine defense areas.

At present the Navy's investigators have consistently applied Law Number 45 of 2009 concerning Amendments to Law Number 31 of 2004 concerning Fisheries by implementing enforcement of law quickly and thoroughly and can have a deterrent effect on the perpetrators. In the process of investigating the Navy base according to the mandate of the Law, the ship owner, agent and operator have been named as suspects. This is done so that the owners no longer take cover behind the body and sacrifice the Captain and the crew of the fishing boat. The Indonesian Navy's investigators must indeed submit to the authority that regulates licensing, even though they are always placed as firefighters and blamed if there is an unfinished case resolution. The Navy's commitment remains high to proactively eradicate illegal fishing practices.

Procedures and procedures for examining criminal acts at sea as part of law enforcement at sea have characteristics or ways that are unique and contain some differences from investigations of crime on land. This is because at sea there are not only national interests, but there are also international interests that must be respected, such as the rights of peaceful crossing, the rights of the archipelagic sea lanes, the right of transit transit, the installation of sea cables and the traditional fisheries of neighboring countries.

The set of rules as supporting law enforcement against illegal fishing in Indonesia is as follows:

1. Law No. 31/2004 and amendments to Law No. 45/2009 concerning Fisheries;

2. Law No. 27 of 2007 concerning Management of Coastal Areas and Small Islands and other implementing regulations such as: Government Regulation Number 54 of 2005 concerning Fisheries Business;

3. Government Regulation Number 60 Year 2007 concerning Conservation of Fish Resources;

4. Government Regulation No. 30/2008 concerning the Implementation of Fisheries Research and Development;

5. Regulation of the Minister of Maritime Affairs and Fisheries Number PER.13 / MEN / 2005 concerning the Coordination Forum for the Management of Criminal Acts in the Field of Fisheries;

6. Regulation of the Minister of Maritime Affairs and Fisheries Number PER.14 / MEN / 2005 concerning the National Commission on the Study of Fish Resources;

7. Regulation of the Minister of Maritime Affairs and Fisheries Number PER.15 / MEN / 2005 concerning Fishing and / or Fish Cultivators in the Fisheries Management Area of the Republic of Indonesia which are not for Commercial Purposes;

8. Regulation of the Minister of Maritime Affairs and Fisheries Number PER.05 / MEN / 2008 concerning Capture Fisheries Business, Regulation of the Minister of Maritime Affairs and Fisheries Number PER.06 / MEN / 2008 concerning Use of Trawl in the North East Kalimantan Waters, Regulation of the Minister of Maritime Affairs and Fisheries Number PER.08 / MEN / 2008 concerning the Use of Ingsang Fishing Net (Gill Net) in the Indonesian Exclusive Economic Zone (IEEZ). 
3. Obstacles in Enforcement of Law Number 45 of 2009 concerning Amendments to Law Number 31 of 2004 concerning Fisheries

\section{a. Barriers to law enforcement against Illegal Fishing}

The object referred to here is the perpetrators involved in Illegal Fishing crime, the perpetrators who are the mastermind of the activity. Particularly in this case are the Acting Officials, the Law Enforcement Officials or Civil Servants who are not specifically regulated in the Law on Fisheries.

The application of Article 56 paragraph (1) of the Criminal Code that qualifies the perpetrators of criminal acts as those who commit, who order to commit and who participate in committing criminal acts can also be applied in Illegal Fishing crimes involving many parties. However, the criminal burden that must be jointly borne in the occurrence of the crime of Illegal Fishing can also reduce the sense of justice of the community, because with the quality and consequences of unequal acts against the perpetrators participating, it can be criminally the same as the maker according to the provisions of Article 56 paragraph (1) The Criminal Code, while in fact the role of the main actors is difficult to find.

\section{Weak Coordination Between Law Enforcement}

Weak coordination between law enforcement agencies can lead to overlapping authority and respective policies, so that it is very prone to cause conflicts of interest. Uncoordinated law enforcement is one of the obstacles in overcoming Illegal Fishing crime.

The judicial process from investigation to trial requires a very large cost, a very long legal process and very adequate facilities / infrastructure requires special expertise in handling the case. In one agency certainly does not have all the components, data / information or facilities and infrastructure needed in the context of law enforcement. Therefore we need synergic coordination and cooperation between agencies involved in efforts to enforce the law against Illegal Fishing.

In eradicating Illegal Fishing crimes that occur in Indonesia, it is often found that one of the obstacles in eradicating Illegal Fishing is caused by the lack of effective and efficient coordination between various relevant agencies, which is in accordance with the Minister of Maritime Affairs and Fisheries Regulation No. PER / 11 / MEN / 2006 concerning Amendment to Ministerial Regulation Number PER / 13 / MEN / 2005 concerning the Coordinating Forum for Criminal Acts in the Field of Fisheries, in this case there are 10 (ten) related agencies that are in a chain of eradicating Illegal Fishing which is crucial in the enforcement process fisheries crime law, namely: Ministry of Maritime Affairs and Fisheries, Indonesian National Police, Indonesian Navy - Navy, Attorney General's Office, Ministry of Law and Human Rights Directorate General of Immigration, Transportation Ministry Directorate General of Sea Transportation, Ministry of Finance Directorate General of Customs and Excise, Ministry of Manpower and Transmigration Directorate General of Supervision Supervision Manpower, Supreme Court and Provincial / Regency / City Regional Government.

Coordination between the various agencies will determine the success in enforcing criminal law against Illegal Fishing crime which is an organized crime that has a very wide network ranging from illegal fishing, fish transportation in the middle of the sea to illegal export of fish. Even so, this matter is not explicitly and clearly regulated the division of authority, as well as definitive working mechanism arrangements, so that between these agencies can declare authority in law enforcement without any system integration in its implementation.

This arrangement can lead to vulnerability in the differences in interpretation of laws and regulations and differences in the pattern of law enforcement among fellow officers, and even fears of disharmony or friction among officials in the eradication of illegal fish. This situation has the potential to cause conflicts of authority in law enforcement. Whereas the conflict of authority is a very unfavorable situation and reflects weak and nonoptimal law enforcement, which has an impact on the existence of criminal acts in the territorial waters of the sea with a high enough frequency and continues to continue.

\section{Formulation of Criminal Sanctions}

The formulation of criminal sanctions in Article Law Number 31 of 2004 and amendments to Law Number 45 of 2009 concerning Fisheries, which has a very severe criminal sanction compared to other criminal provisions, apparently has not given a deterrent effect to the perpetrators of Illegal Fishing crimes. The maximum threat of imprisonment of 6 ( six) years for perpetrators who catch fish without having or carrying SIPI (Fishing License) and a maximum of 7 (seven) years for those who commit forgery and use fake permits in the form of SIUP, SIPI, SIKPI . A maximum fine of Rp. 20,000,000,000 (twenty billion rupiah).

The formulation of sanctions in this Law does not regulate the formulation of the lowest or minimum sanctions so that often the criminal sanctions imposed do not give a deterrent effect to the perpetrators. Likewise, it has not yet been regulated concerning criminal sanctions for Corporations as well as additional criminal sanctions, especially for acts of omission.

Substantially, significant changes to RI Law No. 45 of 2009 compared to RI Law No. The previous 31/2004 was an emphasis on the provision of severe criminal sanctions against foreign vessels committing the crime of fish theft in the Indonesian Exclusive Economic Zone. History of the birth of RI Law No. 45 of 2009 it is implied that the previous law was amended because there were deficiencies. Some things we can look at about the substantial 
changes between Law No. 31 of 2004 with Law No. 45 of 2009 include:

1). The limitation of catching foreign-flagged fishing vessels is not allowed to catch fish in the Indonesian Exclusive Economic Zone Fisheries Management Area of the Republic of Indonesia without having a Fishing License (SIPI) issued by the Government of Indonesia.

2). Indonesia's Exclusive Economic Zone (EEZ). Law No. 31 of 2004 concerning Fisheries article 93 does not clearly state the Indonesian Exclusive Economic Zone (EEZ), but the territory of the Republic of Indonesia Fisheries Management. Through RI Law No. 45 of 2009, the mention of Indonesia's Exclusive Economic Zone has been very firm and clear. The affirmation can be seen in Chapter XV Criminal Provisions Article 93 Paragraph (2) states, "Every person who owns and / or operates a foreign-flagged fishing vessel conducts fishing in ZEEI that does not have SIPI as referred to in Article 27 paragraph (2), sentenced to a maximum imprisonment of 6 (six) years and a maximum fine of $\mathrm{Rp}$. 20,000,000,000 (twenty billion rupiah).

3 ). The matter of the Authority for Investigations and Investigations carried by the Navy and the Civil Servants of the Ministry of Maritime Affairs and Fisheries. Great authority for the Indonesian Navy and Civil Servant Investigators of the Ministry of Maritime Affairs and Fisheries granted by RI Law No. 45 of 2009 to prevent and eradicate fish theft in the Indonesian Exclusive Economic Zone (EEZ) waters of the Republic of Indonesia's Fisheries Management Area is one of the heavy tasks that must be carried out. In carrying out their functions and duties, fisheries investigators and supervisors can take special measures in the form of burning and or sinking of foreign-flagged fishing vessels based on sufficient preliminary evidence.

4). Decision of seizure of objects and / or equipment used in and / or resulting from Fish Theft Crimes. Article 104 paragraph (2) of Law No. 45 of 2009 concerning amendments to Law No. 31 of 2004 concerning Fisheries, is used to place objects and / or tools used in and / or resulting from criminal acts of fish theft into spoils through a Court Decision.

5). Community participation is required. In addition to the Indonesian Navy and the Civil Servant Investigation Ministry of Maritime Affairs and Fisheries and other Law Enforcement, Law No. 45 of 2009 concerning amendments to Law No. 31 of 2004 concerning Fisheries, also included the community to play an active role in efforts to prevent and eradicate criminal acts of fish theft in the Indonesian Exclusive Economic Zone.

6). Not concerned with the element of intent. Crime of fish theft in the waters of the Indonesian Exclusive Economic Zone "every person who owns and / or operates" in several articles of Law No. 45 of 2009 concerning amendments to Law No. 31 of 2004 concerning Fisheries with no regard to intentional elements, can ensnare people who actually have no intention of committing the crime of fish theft in the Indonesian Exclusive Economic Zone.

7). The use of a criminal system. The use of the prison system of crimes against perpetrators of fish theft crimes by foreign fishermen in the Indonesian Exclusive Economic Zone (EEZ) Fisheries Management Area of the Republic of Indonesia is not enforced. Arrests must not be carried out by investigators. When arrested at the crime scene, then the suspect is brought to be processed by making the Minutes of Investigation (BAP). After being investigated, the suspect must be immediately returned to his home country without being detained in advance.

8). Equation of Punishment for Trials and Crimes in accordance with Indonesian Law No. 45 of 2009 concerning amendments to RI Law No. 31 of 2004 concerning Fisheries, equating criminal penalties for perpetrators of criminal acts completed with the perpetrators of criminal trials. The Crime of Fish Theft in the Indonesian Exclusive Economic Zone (EEZ) is a crime because the act has a huge effect which is detrimental to the State of approximately 30 trillion rupiah per year.

2009 concerning amendment of Law No. 31 of 2004 concerning Fisheries can be grouped in terms of forms of their actions, namely crime and violations. Acts categorized as crimes as regulated in Articles 84, 85, 86, 88, 91, 92, 93, 94, and 94A. The forms of acts that are categorized as violations as regulated in Article 87, 89, 90, 95, 96, $97,98,99,100,100 \mathrm{~A}, 100 \mathrm{~B}, 100 \mathrm{C}$, and 100D.

The classification of crimes and violations in the aforementioned fisheries criminal offenses is in accordance with the formulation of criminal law which states the following matters:

a). Criminal Law is part of the whole law in force in a country.

b). Acts which are forbidden by criminal law and threatened with criminal conduct.

c). Criminal law determines which actions are seen as criminal acts.

d). Anyone who commits a criminal offense is threatened with a criminal offense.

e). Criminal law regulates criminal liability (criminal liability).

f). Some opinions about the definition of criminal law.

g). Matters need to be emphasized regarding our understanding of criminal law.

Based on the formulation, in fisheries criminal act, it can be clearly seen whether it is in the form of a crime 
or violation committed by the perpetrators of fish theft and what criminal will be given to violators of the existing fisheries regulations. Apart from all that the community as a party lay to the law will always question the Court's decision with unprofessional practices by law enforcement officials including PPNS Fisheries, TNI - Navy, Police Investigators, Prosecutors and Judges but of course this must have a strong basis so that law enforcement agencies themselves are not disadvantaged by accusations - baseless accusations. Conversely, if the allegations are proven, then the person of law enforcement must be immediately dealt with firmly based on the rule of law and this means that law enforcement agencies need to make updates.

In punishing criminal offenders, fisheries must be understood in more depth and the basis of the conviction must be known. The criminal and criminal system in the classical school strongly emphasizes the punishment of an act, not the culprit. This means that the stipulation of sanctions in the law does not use a system of mitigation or weighting related to the age factor, mental state of the offender, crimes committed previously or specific circumstances of the act / crime committed. Modern streams that look for causes of crime by using natural science methods and intend to directly approach or influence criminals positively as long as they can still be corrected. Therefore this flow starts from the view of determinism and requires the existence of criminal individualism that aims to conduct a resocialization of perpetrators of crime.

The purpose of punishment according to Wirjono Prodjodikoro, namely: 1). To frighten people not to commit crimes either by scaring people (general preventive) or scaring certain people who have committed crimes so that later they do not commit crimes again (special preventive), or 2). To educate or correct those who commit crimes so that they become good people of character so as to benefit the community. P.A.F. Lamintang states that basically there are three main ideas about the objectives to be achieved with a conviction, namely: 1). To correct the person of the criminal himself, 2). To make people become deterrent in committing crimes, and 3). To make certain criminals unable to commit other crimes, that is, criminals who in other ways are irreparable.

\section{b. Efforts Made Against Obstacles In Illegal Fishing Law Enforcement}

It is realized that the problem of illegal fishing is a multi-actor problem in the context of involving many parties (fishing communities, government and fisheries actors), multi-level because it also involves global (foreign) actors especially those related to fishing ground conflicts, multi-lateral cooperation in sub-regional as well as regional and multi-mode levels, especially those related to regulatory regulations, law enforcement, to the provision of supervisory facilities and infrastructure. By considering the dual effects arising from the problem of illegal fishing as previously described, the government must implement two strategies simultaneously, namely the internal strategy and the external strategy.

The inward strategy consists of four strategies. First, reforming the fisheries legal and justice system. Weak legal products as well as low mental law enforcement at sea are the main problems in handling illegal fishing in Indonesia. However, with the passing of RI Law No. 45 of 2009 concerning Fisheries, it is expected that law enforcement at sea can be carried out. In this fisheries law the sanctions imposed on the perpetrators of illegal fishing are quite heavy. An example is that the Law requires that every fishing vessel must have a fishing license (SIPI). For Indonesian-flagged vessels that violate the provisions, the manager and owner of the ship can be punished by imprisonment for six years and a fine of Rp. 2 billion. If violations are carried out by foreign-flagged vessels, the ship's management and owner are threatened with imprisonment for six years and a fine penalty of Rp. 20 billion. In addition, the Act also confirms that the examination at the court hearing can be carried out without the presence of the Defendant.

The judge must also make a decision no later than 30 (thirty) days from the date of receipt of the case file transfer from the Public Prosecutor. The same time period applies to Judges of the Court of Appeal and the Supreme Court in deciding appeals and decisions. In other words, the handling of the Fisheries Court can be done quickly and efficiently given the characteristics of the fisheries which are rotten quickly. With this ad-hoc court, it is hoped that the value of salvaged fish can increase while helping to reduce damage to foreign vessels that are confiscated, which can be donated to national fishermen.

The existence of this fisheries law must be supported by law enforcement officers at sea, with a strong fleet and mentality and enthusiasm to enforce the law is the key to the implementation of the fisheries law to overcome the problem of illegal fishing.

Secondly, increasing law enforcement apparatuses by developing and strengthening surveillance capabilities (law enforcement) at sea, can be done through several things, namely:

a. The implementation of the MCS (Monitoring, Control and Surveillance) system, one of which is to use VMS (Vessel Monitoring Systems) as recommended by FAO. Simply put, this system consists of a database system based on a geographic information system (GIS), so that VMS operators can monitor all ship positions in a particular water area. Thus the presence of foreign fishing vessels can be immediately identified so that further action can be taken.

b. Empowering and increasing institutional capacity and oversight organizations in the community (community - based monitoring). With efforts to increase awareness of the importance of fisheries and marine resources for their lives and the preservation of ecosystems, it is hoped that local fishermen can 
monitor their fishing grounds from destructive and illegal fishing efforts. This community-based supervision system is also implemented in developed countries. Japan, for example, has been implementing this system for a long time especially in relation to the implementation of "gyogyou ken" (fishing rights) for certain fishing communities. With the spearhead of "Gyyogyou kumiai" (fisheries cooperatives), the local fishing community oversees the area of their capture from illegal fishing.

c. Fulfillment of supervision facilities and infrastructure needs in stages according to priorities and needs.

d. Improve coordination and cooperation with related cross-sector agencies in the field of supervision.

Third, refinement of the capture fisheries system and licensing mechanism. The number of fishing vessels permitted to operate in a fishing area does not exceed the number of allowed catches ( $80 \% \mathrm{MSY})$ so that the fishing business can take place profitably and sustainably. In addition, there are gradually no more fishing permits for foreign fishing vessels in ZEEI waters. And the most important is the procedure for obtaining permits in a transparent and fast manner. Specifically to overcome the problem of foreign fishing vessels conducting illegal fishing, a strategy that can be carried out is a moratorium on foreign fishing vessels.

Granting permission for foreign vessels to operate in Indonesian territorial waters is not a "legalization" strategy of illegal foreign vessels, but instead is one of the exit strategies from the problem of illegal fishing. Because granting such permission is not without conditions. One of them is that the foreign vessel is required to land its fish in the territorial waters of Indonesia and the foreign vessel owner country must be willing to contribute to the development of fishery facilities in fishing landing centers in the Indonesian territory.

Fourth, improvement of infrastructure facilities, namely strengthening (modernizing) the national fishing fleet. One of the causes of the rampant illegal fishing practices in ZEEI is the small number of Indonesian fishing vessels operating in the ZEEI area due to their low fleet capability (short range capability and short sailing time). This causes foreign fishermen to freely catch fish in the ZEEI area. In other words, we must make our fishermen host their own sea.

Whereas the exit strategy (external strategy) is related to the importance of regional and international cooperation, especially those related to neighboring countries. By increasing this role there are 2 (two) benefits at the same time. First, Indonesia can ask other countries to impose sanctions on vessels that catch fish illegally in Indonesian waters as described above. By implementing an anti-illegal fishing policy regionally, efforts to steal fish by foreign vessels can be reduced as low as possible. This has for example been carried out in the form of a Joint Commission Sub-Committee of Fisheries Cooperation between Indonesia and Thailand and the Philippines to discuss issues of fisheries and delimitation of EEZ boundaries between countries. This collaboration can also be applied in the context of reducing the operational costs of MCS so that joint operations for VMS for example can be carried out.

Secondly, by joining Indonesia into the international fisheries organization, Indonesia has indirectly stopped the practice of "non-member fishing" which is done so that Indonesian fishery products can be relatively 'accepted' by the international market. In the past, the reluctance of the Indonesian government to join the regional / international fisheries organization was more due to the obligation to pay member fees. But as the global trend of the importance of eradicating illegal fishing practices continues to increase, prevention efforts through international organizations still need to be gradual.

\section{Closing}

Law No. 45 of 2009 concerning Amendments to Law Number 31 of 2004 Concerning Fisheries, does not regulate the division of authority expressly nor does it regulate certain work mechanisms, so that the three agencies namely the Ministry of fisheries and Maritime Affairs, the Ministry of Home Affairs and Local Governments state the same institution - is equally authorized in law enforcement in fisheries as well as in the absence of an integrated system in its implementation.

Conflicts of authority like this are not beneficial and reflect law enforcement against fisheries criminal offenses considered weak and not optimal, so that the impact on illegal fishing activities still shows a high enough frequency and continues to continue. For this reason, a solution is immediately sought, in order to create an orderly, safe condition and legal certainty. This has a positive effect on businesses in the field of fisheries, which in turn can improve the welfare of the community.

In accordance with the above, it is necessary to improve the ability and competence of human resources, especially at the Prosecution and Court level so that in the process of resolution or law enforcement against Illegal Fishing can be done professionally and on target so that it is expected that the objectives of the integrated criminal justice system in tackling crime in the field of fisheries can be achieved.

Likewise, it is necessary to establish a Coordination Forum for Law Enforcement Officials in the field of Fisheries so that the handling of Illegal Fishing criminal cases can be carried out jointly across sectors so that what is an inhibiting factor in law enforcement efforts in the field of fisheries can be minimized. 


\section{BIBLIOGRAPHY}

Arief, Barda Nawawi. 2006. Kapita Selekta Hukum Pidana Tentang Sistem Peradilan Terpadu. Semarang: Badan Penerbit Universitas Diponegoro.

Atmasasmita, Romli. 2005. Kapita Selekta Hukum Pidana dan Kriminologi. Bandung: Mandar Maju.

Badan Pusat Statistik Provinsi Sumatera Selatan. 2007. Sumatera Selatan dalam Angka Tahun 2007.

Barda Nawawi Arief. 2006. Kapita Selekta Hukum Pidana Tentang Sistem Peradilan Terpadu. Semarang: Badan Penerbit Universitas Diponegoro,

Chazawi, Adami. 2002. Pelajaran Hukum Pidana Stelsel Pidana, Tindak Pidana, Teori-Teori Pemidanaan Dan Batas Berlakunya Hukum Pidana. Jakarta: PT. Rajagrafindo Persada.

Dahuri, Rokhmin, 2003, Keaneragaman Hayati Laut-Aset Pembangunan Berkelanjutan Indonesia. Jakarta: Gramedia Pustaka Utama.

Djalal, Hasjim. 1979, Perjuangan Indonesia Di Bidang Hukum Laut, Bandung: Binacipta.

Djoko Prakoso. 2000. Pembaharuan Hukum Pidana di Indonesia, Penerbit Yogyakarta: Liberty.

Djoko, Tribowo H. 2012. Hukum Perikanan Indonesia, Bandung: Penerbit PT. Citra Aditya Bakti.

Effendi I, Oktariza W. 2006. Manajemen Agribisnis Perikanan. Jakarta. Penebar Swadaya.

Effendi I, Oktariza W. 2016. Manajemen Agribisnis Perikanan. Jakarta. Penebar Swadaya

Efrizal, Syarief. 2011. Pembangunan Kelautan Dalam Konteks Pemberdayaan Masyarakat Pesisir, Jakarta: Majalah PP.

Fauzi, A. 2014. Ekonomi Sumber daya Alam dan Lingkungan:Teori dan Aplikasi. Jakarta: PT Gramedia PustakaUtama.

Gjertsen, H. 2005. "Can Habitat Protection Lead to Improvements in Human Well-Being? Evidence from Marine Protected Areas in the Philippines". World Development.

Hastuti, Novi. 2010. Pengelolaan Sumber Daya Alam Dengan Koefisiensi, Pembangunan Berkelanjutan dan Berwawasan Lingkungan. Bulletin Online Edisi Januari - Februari 2010.

Indri novita, 2014 ekonomi perikanan kebijakan pengelolaan peranan berwawasan lingkunga. Jakarta: Pustaka.

Irvan, Muhammad. 2013. Adaptasi Masyarakat/Kearifan Lokal dalamPengelolaan Perikanan Berkelanjutan. Yogyakarta: Jurnal Ilmu Lingkungan.

Joko Sumaryono. 2007. Forum Koordinasi dan Konsultasi Operasi Keamanan Laut dan Penegakan Hukum, Jakarta: Majalah Patriot.

Joko, Subagyo P. 2003. Hukum Laut Indonesia, Jakarta: Penerbit Rineka Cipta.

Kusumaatmadja, Mochtar. 1999, Perlindungan dan Pelestarian Lingkungan Laut Dilihat dari Sudut Hukum Internasional, Regional dan Nasional. Jakarta: Sinar Grafika dan Pusat Studi Wawasan Nusantara.

Mallawa, A. 2006. "Pengelolaan Sumber Daya Ikan Berkelanjutan dan Berbasis Masyarakat". Disampaikan dalam Lokakarya Agenda Penelitian Program COREMAP II. Kabupaten Selayar, 9-10 September 2006.

Merino, G. B. et al. 2008. "Assessment and Bioeconomic Analysis of The Majorca (NW Mediterranean) Trammel Net Fishery". Aquatic Living resources.

Mubyarto 1989. Alat Tangkap Perikanan. Jakarta:LP3ES.

Ningsih dan Heri. 2012. Strategi Pengelolaan dan Pemanfaatan Sumber Daya Kelautan dan Perikanan. Jakarta: Deputi Bidang Sumber Daya Alam dan Lingkungan Hidup Direktorat Kelautan dan Perikanan.

Pramono Djoko, 2015. Budaya Bahari, Jakarta: PT Gramedia Pustaka Utama.

Prihartono E.R, Rasidik J, Arie U. 2012. Pelanggaran Alat Tangkap Bogor: Penebar Swadaya.

Romli Atmasasmita. 2008. Kapita Selekta Hukum Pidana dan Kriminologi, Bandung: Mandar Maju.

Rudy T. May,2011. Hukum Laut Internasional 2, Bandung: Refika Aditama.

Satria, A.2012. "Prospek Ekonomi Kelautan dan Perikanan 2013". Harian Tempo, 27 Desember 2012.

Subani W dan HR Barus. 1989. Alat Penangkapan Ikan dan Udang Laut di Indonesia. Jurnal Penelitian Perikanan Laut. No. 50. Jakarta: Balai Penelitian Perikanan Laut Badan Penelitian dan Pengembangan Pertanian. Departemen Pertanian.

Suhana. 2009. Pengelolaan Sumber Daya Pesisir dan Laut Dalam PerspektifKearifan Lokal Desa Autubun, Maluku Tenggara Barat. Bulletin Online Edisi November - Desember 2009. ISSN 1978 - 1571.

Sumaryono, Joko. 2007. Forum Koordinasi dan Konsultasi Operasi Keamanan Laut dan Penegakan Hukum. Jakarta: Majalah Patriot.

Supriadi.2011. Hukum Perikanan Di Indonesia. Jakarta: Sinar Grafika.

Supriyanto. 2013. Analisis Pengelolaan Pelabuhan Perikanan Berwawasan Lingkungan Di Pelabuhan Perikanan Samudera Nizam Zachman. Jakarta. Jurnal Ilmu Lingkungan 2013:7 (2).

Suyanto R. 2007. Evaluasi Alat Tangkap. Jakarta. Penebar Swadaya.

Teguh, Muhammad. 2011. Metodologi Penelitian Ekonomi Teori dan Aplikasi. Jakarta. PT RajaGrafindo Persada. Tribawono, H. Djoko Tribawono, 2002, Hukum Perikanan Indonesia, Bandung: Citra Aditya Bakti. 


\section{PERATURAN PERUNDANGAN}

Undang-Undang Nomor 16 Tahun 2006 tentang Sistem Penyuluhan Pertanian, Perikanan dan Kehutanan.

Undang-Undang Nomor 27 Tahun 2007 tentang Pengelolaan Wilayah Pesisir dan Pulau-Pulau Kecil.

Undang-Undang Nomor 31 Tahun 2004 tentang Perikanan.

Undang-Undang Nomor 45 Tahun 2009 tentang Perubahan Atas Undang-Undang Nomor 31 Tahun 2004 tentang Perikanan.

TAP MPR Nomor II/MPR/ 1983 tentang Garis-Garis Besar Haluan Negara.

Undang-Undang Republik Indonesia Nomor 19 Tahun 1961 Tentang Persetujuan Atas Tiga Konvensi Jenewa Tahun 1958 Mengenai Hukum Laut.

Ordonansi Perikanan Mutiara dan Bunga Karang (Algemeene Regelen voor het Visschen naar Parelschelpen, Parelmoerschelpen, Teripang en sponsen binnen de afstand van neet meer dan drie engelschezeenijlen van de kusten van Nederlandsch Indie, Stb. 1916 No. 157),

Ordonansi Perikanan untuk Melindungi Ikan (Visserij Bepaling ter Bescherming van de Visscheestand, Stb. 1920 No. 396),

Algemeene Regeling voor Visscherij binnen den afstad van Nederlandsch Indie(Stb 1927 Nomor 144),

Algemeene Regelen voor de jacht op walvissechen binnen den afsta van drie zeemijlen van de kusten van Nederlandsch Indie(Stb 1927 Nomor 145),

Peraturan Pendaftaran kapal-kapal Nelayan Laut Asing (Stb. 1938 No. 201), Ordonansi Laut Teritorial dan Lingkungan Maritim (Territoriale Zee en Maritieme Kringen Ordonantie, Stb. 1939 No. 44.

\section{INTERNET}

(https://www.academia.edu/17917933/Ekonomi_Perikanan_Kebijakan_Pengelolaan_Peranan_Berwawasan_Lin gkungan ).

ttp://statistik.dkp.go.id/index.php?start=search\&mod=6

http://www.dkp.go.id/content.php?c=282.

PenebarSwadaya. http://id.wikipedia.org/wiki/Pecel_lele http://amperawisata digital.info/peta.php.

http://www.bppp-tegal.com/web/index.php/artikel/182-pengelolaan-sumberdaya-perikanan-yang-berkelanjutan. 